\title{
Changes in microbial loop components: effects of a harmful algal bloom formation and its decay
}

\author{
Takashi Kamiyama*, Shigeru Itakura, Keizo Nagasaki \\ National Research Institute of Fisheries and Environment of Inland Sea, Maruishi 2-17-5, Ohno, Saeki, \\ Hiroshima 739-0452, Japan
}

\begin{abstract}
Temporal changes in microbial loop components during the formation and decay of a bloom caused by the harmful microalga Heterosigma akashiwo (Raphidophyceae) were investigated in 1995 at a site in northern Hiroshima Bay, the Seto Inland Sea of Japan. A surface bloom of H. akashiwo, the density of which exceeded $10^{4}$ cells $\mathrm{ml}^{-1}$, was recorded in early summer at surface temperatures ranging from 21.6 to $23.2^{\circ} \mathrm{C}$. Although the abundance and species diversity of tintinnid ciliates decreased in the surface layer when the density of $\mathrm{H}$. akashiwo exceeded $10^{4} \mathrm{cells} \mathrm{m}^{-1}$, aloricate ciliates increased evidently at the end of the bloom. In addition, the mean ciliate biomass in the surface and near bottom layers reached the same level as the bacterial biomass. Two peaks in bacterial abundance and biomass were recorded during the formation and at the end of the bloom, and fluctuations in the abundance of heterotrophic nanoflagellates (HNF) clearly corresponded with fluctuations in bacterial abundance, with a lag period of 1 to $3 \mathrm{~d}$. The increase of each microbial loop component during the course of the $H$. akashiwo bloom suggests that the dissolved organic matter produced from $H$. akashiwo cells temporarily enhanced the energy flow from bacteria through HNF to bacterivorous aloricate ciliates.
\end{abstract}

KEY WORDS: Heterosigma akashiwo - Bloom - Red tide - Microbial loop - Bacteria - Flagellate - Ciliate Abundance

\section{INTRODUCTION}

Since the concept of the microbial loop was proposed by Azam et al. (1983), the roles of its components, such as bacteria, heterotrophic nanoflagellates (HNF) and ciliates, have been investigated in coastal waters. Consequently, previous studies have demonstrated that the biomass of bacteria is equal to or exceeds that of phytoplankton (Simon et al. 1992), and its production is equivalent to $30 \%$ of the primary production based on phytoplankton (Cole et al. 1988). Simultaneously, ecological studies on the other microbial loop components have revealed that they can play important roles as bacteria grazers (Fenchel 1982, Sieburth 1984, Sherr \& Sherr 1987 ) and that they are also consumed by various net-zooplankton (Stoecker \& Capuzzo 1990, Pierce \& Turner 1992). These results suggest that some parts

\footnotetext{
•E-mail: kamiyama@.affrc.go.jp
}

within the microbial loop effectively link the grazing food chain and may enhance fisheries production (Sherr et al. 1986, Sherr \& Sherr 1988). However, there is a possibility that bacterial production is not linked to higher trophic levels because of many steps of transfer loss (Ducklow et al. 1986). In eutrophic marine ecosystems, it is likely that bacterial production strongly influences planktonic food webs, which enhance the productivity of higher trophic levels, even if there are many steps of transfer loss. This is because bacterial biomass and production are very high in such areas. From this point of view, the function of microbial loops is important in coastal fisheries production.

The blooms of Heterosigma akashiwo (previously referred to as Heterosigma carterae or Olithodiscus luteus) have been observed in coastal waters throughout the world. Heavy blooms of $H$. akashiwo have been associated with cultured fish mortality (Chang et al. 1990, Honjo 1993). Furthermore, H. akashiwo blooms probably weaken trophic links within grazing food 
webs in coastal waters. Many micro- and macrozooplankton reject $H$. akashiwo cells as a food source. The collapse of tintinnid ciliate populations due to blooms of $H$. akashiwo is well documented (Verity \& Stoecker 1982, Kamiyama 1995). The calanoid copepod Acartia omorii has been found to almost completely reject $H$. akashiwo due to the intracellular chemical compounds in this alga (Uye \& Takamatsu 1990). Inhibition of the feeding activity and reproduction of the rotifer Synchaeta cecila caused by H. akashiwo has also been reported when more than 1000 cells $\mathrm{ml}^{-1}$ of this alga are present (Egloff 1986).

The northern part of Hiroshima Bay is one of the most highly enclosed and eutrophic areas in the Seto Inland Sea. In this area, blooms of Heterosigma akashiwo often occur in early summer, as well as other harmful algal blooms (e.g. Matsuyama et al. 1997). Nevertheless, the productivity of planktivorous fish such as anchovy and sardine in Hiroshima Bay is very high (Hashimoto et al. 1997). It is therefore essential to clarify the effects of these blooms on the structure of planktonic food webs in order to elucidate the fisheries production system in this bay. To our knowledge this is the first study of temporal changes in microbial loop components in the whole process of a $H$. akashiwo bloom.

\section{MATERIAL AND METHODS}

The investigation was conducted in a harbor (ca $5 \mathrm{~m}$ water depth. Stn V in Nagasaki et al. 1994) in the northern part of Hiroshima Bay, the Seto Inland Sea. Sampling was carried out every 1 to $4 \mathrm{~d}$ between 09:00 and 11:00 h during the course of a Heterosigma akashiwo bloom from June 6 to July 17, 1995. This site is located in a closed area where water currents from outer areas are negligible. Vertical profiles of temperature and salinity were measured with a temperaturesalinity bridge (YEO-KAL model 602). Seawater was collected at the surface with a plastic bucket and at $1 \mathrm{~m}$ above the bottom (B-1 m) with a Niskin bottle sampler. Water samples were transported to the laboratory within 2 h. $H$. akashiwo and other dominant species of phytoplankton were counted in triplicate in 0.05 to $1 \mathrm{ml}$ of fresh seawater from each depth.

Part of the seawater from each depth was filtered through a glass-fiber filter (Whatman GF/F). The chlorophyll a (chl a) on the filter was extracted with N, N-dimethylformamide at $-20^{\circ} \mathrm{C}$ under dark conditions (Suzuki \& Ishimaru 1990), and then measured with a Turner Designs fluorometer. In the filtrate obtained by filtration of another seawater sample with Millipore Milex HV-filter (pore size: $0.45 \mu \mathrm{m}$ ), concentrations of nutrient salts $\left(\mathrm{NO}_{2}-\mathrm{N}, \mathrm{NO}_{3}-\mathrm{N}, \mathrm{NH}_{4}-\mathrm{N}, \mathrm{PO}_{4}-\mathrm{P}, \mathrm{SiO}-\mathrm{Si}\right.$ ) were measured using a TrAAcs 800 autoanalyzer
(Bran-Luebbe Co.), based on the method of Strickland \& Parsons (1968).

A $200 \mathrm{ml}$ seawater sample was fixed with Lugol's iodine solution (final concentration: $2 \%$ ), and then concentrated by settling to a volume of 1 to $6 \mathrm{ml}$. Microzooplankton (zooplankton with body widths less than $200 \mu \mathrm{m}$ ) of each subsample were counted in 1 to $2 \mathrm{ml}$ of concentrated samples with a phase contrast microscope at a magnification of $\times 150$, using a SedgwickRafter chamber. The large mixotrophic dinoflagellate Gymnodinium sanguineum was identified and counted in fixed samples. However, it was not possible to identify the other mixotrophic and heterotrophic dinoflagellates. In the ciliate community, most of the tintinnids were distinguished into species by lorica morphology based on the same references used by Kamiyama \& Tsujino (1996). The species diversity $\left(H^{\prime}\right)$ of tintinnids for each sample was calculated using the Shannon-Wiener function (Shannon \& Weaver 1963):

$$
H^{\prime}=-\sum_{i=1}^{s}\left(n_{i} / N\right) \log _{2}\left(n_{i} / N\right)
$$

where $n_{1}$ is the abundance (ind. $\mathrm{l}^{-1}$ ) of $i$ species, $N$ is the total abundance (ind. $\mathrm{l}^{-1}$ ), and $s$ is the number of species.

Since heterotrophic and mixotrophic aloricate ciliates could not be readily identified into genus or species, they were grouped into separate morphotypes which were based on size and shape. In the present study, the autotrophic ciliate Mesodinium rubrum (= Myrionecta rubura) was not included in the aloricate ciliates. The length of an appropriate lorica or cell dimension was measured using a calibrated ocular micrometer for up to a maximum of 10 individuals for each taxon. The mean lorica volume for tintinnids and the mean cell volume for aloricate ciliates were calculated by approximating the shape of each ciliate taxon to a standard geometric configuration.

Seawater in each sample was fixed by glutaraldehyde (final concentration: $1 \%$ ), and then bacteria and HNF abundance were quantified with an epifluorescent microscope according to the method of Iwamoto et al. (1994), who basically followed the procedure of Porter \& Feig (1980) and Sherr \& Sherr (1983a,b). Each day, bacteria in $0.3 \mathrm{ml}$ of the fixed subsample were stained with $4^{\prime}$, 6-diamidino-2-phenylindole (DAPI; final concentration: $0.5 \mu \mathrm{g} \mathrm{ml}^{-1}$ ), and then filtered onto a Sudan black B-stained Nucleopore polycarbonate filter (pore size: $0.2 \mu \mathrm{m}$ ) with less than $300 \mathrm{~mm} \mathrm{Hg} \mathrm{vac-}$ uum pressure. The HNF in 5 to $20 \mathrm{ml}$ of the fixed subsample was stained with DAPI (final concentration: $0.1 \mu \mathrm{g} \mathrm{ml}^{-1}$ ) and fluorescein isothiocyanate (FITC; final concentration: $1 \mu \mathrm{g} \mathrm{ml}^{-1}$ ) solutions and then filtered onto a Sudan black B-stained Nucleopore filter (pore size: $1.0 \mu \mathrm{m}$ ) with less than $100 \mathrm{~mm} \mathrm{Hg}$ vacuum pressure. With regard to bacteria, at least 200 cells in more 
than 10 fields, and for HNF at least 50 cells in more than 25 fields, were counted with an epifluorescent microscope at $1250 \times$ magnification. The length and width of each HNF cell were measured using a calibrated ocular micrometer, and then the cell volume was calculated as an ellipse sphere shape.

The carbon contents of tintinnid ciliates $(\mathrm{Ct}, \mathrm{pg})$ were estimated by fitting the lorica volume $\left(\mathrm{LV}, \mu \mathrm{m}^{3}\right)$ of each species in the equation: $\mathrm{Ct}=444.5+0.053 \mathrm{LV}$ (Verity \& Langdon 1984), and the Ct of aloricate ciliate cells preserved in $2 \%$ Lugol's iodine solution were calculated from cell volume data using a carbon conversion factor of $0.19 \mathrm{pg} \mathrm{C} \mathrm{mm}^{-3}$ (Putt \& Stoecker 1989). The $\mathrm{Ct}$ of bacteria were converted from the mean cell volume $\left(0.098 \mathrm{\mu m}^{3} \mathrm{cell}^{-1}\right)$ from annual Hiroshima Bay data (Imai \& Yamaguchi 1996), using a carbon conversion factor of $0.14 \mathrm{pg} \mathrm{C} \mathrm{m}^{-3}$ (Nagata \& Watanabe 1990). The carbon values of HNF were estimated from measured cell volumes, using a carbon conversion factor of $0.07 \mathrm{pg} \mathrm{C} \mathrm{mm}^{-3}$ (Sorokin 1979).

\section{RESULTS}

\section{Phytoplankton and environmental conditions}

A Heterosigma akashiwo bloom with a cell density of over $10^{4}$ cells $\mathrm{ml}^{-1}$ occurred from June 23 to July 1 (hereafter we define this period as the bloom period), with surface temperatures ranging from 21.6 to $23.2^{\circ} \mathrm{C}$ (Fig. 1A,D). In the other phytoplankton, Prorocentrum spp. also increased in density to more than $10^{4}$ cells $\mathrm{ml}^{-1}$ during the bloom period of $H$. akashiwo (Fig. 1E). The abundance of diatoms was low before and during the bloom period, probably indicating that diatoms did not influence the population dynamics of $H$. akashiwo. During the bloom period, the chl a concentration in the surface layer reached $454 \mu \mathrm{g} \mathrm{l}^{-1}$ (Fig. 1C). After the end of the bloom period, the salinity markedly decreased due to rainfall (Fig. 1B). After July 10, when the surface salinity recovered more than $12 \mathrm{psu}$, the chl a concentration increased again. This was caused by increasing diatoms in the phytoplankton community.

All nutrient concentrations changed similarly in the surface and $\mathrm{B}-1 \mathrm{~m}$ layers. The DIN ( $=\mathrm{NO}_{2}-\mathrm{N}+$ $\mathrm{NO}_{3}-\mathrm{N}+\mathrm{NH}_{4}-\mathrm{N}$ ) concentrations in both layers were almost exhausted by phytoplankton during the bloom period (Fig. 1F). Phosphorous concentrations were also low during the bloom period but spiked increases in the surface layer were detected occasionally and a faint increase in the B-1 m layer was observed around the end of the bloom (Fig. 1G). No evident fluctuation of $\mathrm{SiO}_{2}$-Si concentration was observed before or during the bloom period (Fig. $1 \mathrm{H}$ ). Clear increases of $\mathrm{SiO}_{2}-\mathrm{Si}$ after the end of bloom were caused by the large influx of inland fresh water. In the bloom period, the DIN:P ratio decreased (Fig. 1I) and the Si:DIN ratio increased, suggesting that the DIN concentration strongly limited the growth of phytoplankton rather than the $\mathrm{PO}_{4}$-P or $\mathrm{SiO}_{2}-\mathrm{Si}$ concentrations. The $\mathrm{Si} P$ ratio gradually decreased in the latter half and after the bloom, particularly in the B-1 m layer (Fig. 1J). This is likely due to the increase of the $\mathrm{PO}_{4}-\mathrm{P}$ concentration during this period although the $\mathrm{SiO}_{2}-\mathrm{Si}$ concentration did not change obviously.

\section{Microzooplankton community}

Before the bloom of Heterosigma akashiwo, the abundance of tintinnids in both layers ranged from $1.5 \times 10^{2}$ to $7.0 \times 10^{3}$ ind. $1^{-1}$ (Fig. 2A). At the initial stage of the bloom (June 24), the abundance reached a maximum of $1.1 \times 10^{4}$ ind. $\mathrm{I}^{-1}$ in B-1 m layer, and this group temporarily numerically dominated in the ciliate community. However, the abundance of tintinnids in the surface layer markedly decreased by 1 order of magnitude during the bloom period compared to before the bloom. For about $1 \mathrm{wk}$ after the bloom, the abundance of tintinnids remained at a low level and then recovered to the same level as before the bloom. The $H^{\prime}$ of tintinnids in the surface layer also decreased during the bloom (Fig. 2B). The decrease of diversity was observed at the same time as the bloom formation, which was earlier than the point of time when the decrease in abundance of tintinnids started.

Before the bloom, the abundance of aloricate ciliates, which numerically dominated the ciliate community except on June 20 , ranged from $7.2 \times 10^{2}$ to $10.0 \times 10^{3}$ ind. $1^{-1}$ (Fig. 2C). Although a conspicuous change was not observed during the process of bloom formation, the abundance increased drastically at the end of the bloom, and temporarily became 2 orders of magnitude higher than before the bloom. After the end of the bloom, aloricate ciliate abundance in the surface layer decreased for $2 \mathrm{~d}$ and then recovered to the same level as before the bloom, a similar pattern as for other organisms.

Abundance of the mixotrophic dinoflagellate Gymnodinium sanguineum increased in the early stage of the bloom to a maximum of $1.3 \times 10^{3}$ ind. $\mathrm{ml}^{-1}$ on June 25 (Fig, 2F). However, this dinoflagellate decreased rapidly before the end of the surface bloom (July 30).

Densities of copepod nauplii and other metazoans (small copepods, copepodites, appendicularian, rotifers, larvae of bivalves, etc) were in the order of magnitude of $10^{2}$ ind. $\mathrm{l}^{-1}$ before the bloom formation, although the other metazoans often exceeded $10^{3}$ ind. $\mathrm{l}^{-1}$ during and after the bloom (Fig. 2D,E). In general, the variation in the abundance of the other metazoans was similar to that in temperature. 

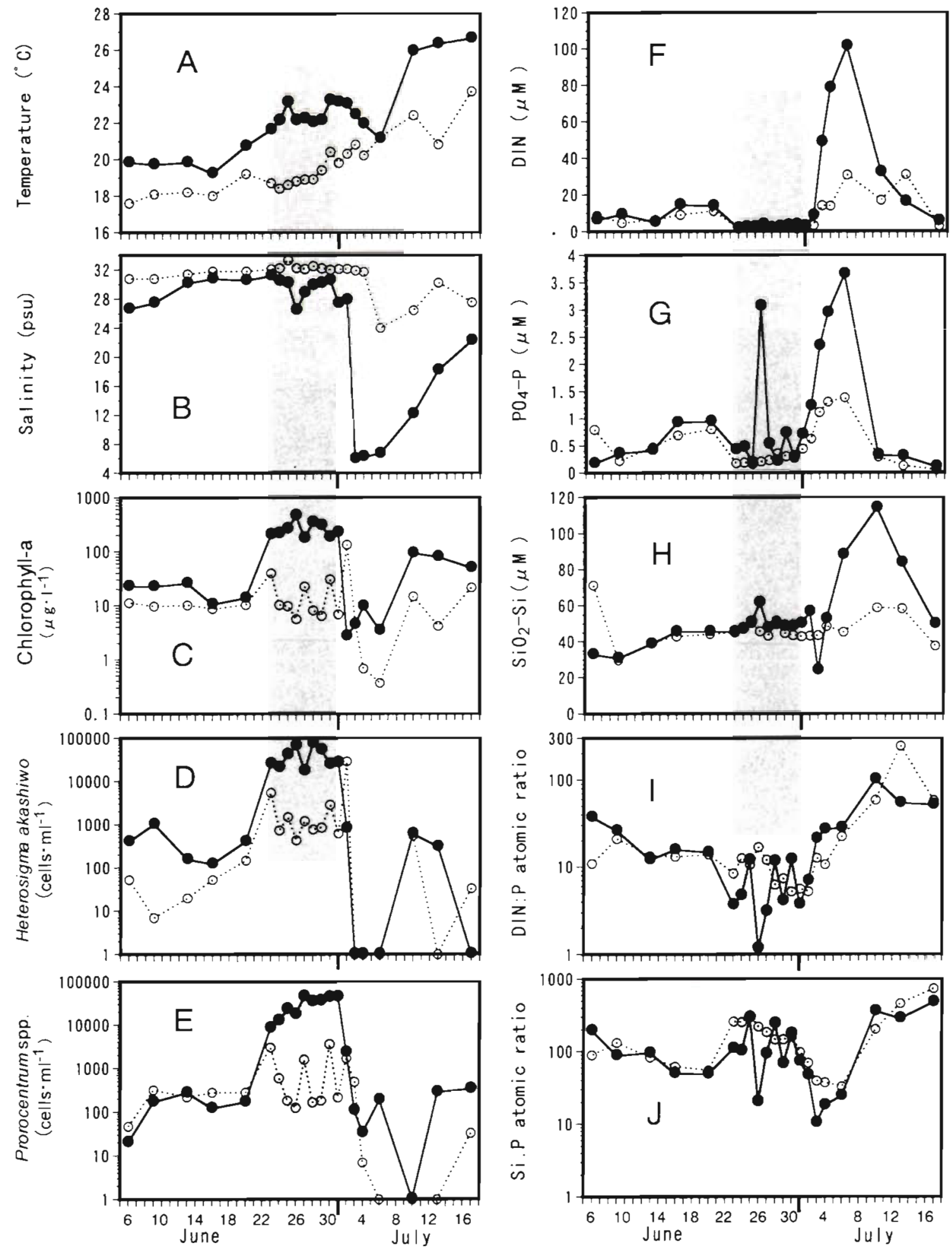

Fig. 1 Temporal changes in the hydrographic conditions and phytoplankton abundance at the surface ( $)$ and $1 \mathrm{~m}$ above the bottom (O) during the course of a Heterosigma akashiwo bloom. Shaded areas indicate the bloom period (June 23 to July 1, 1995) when the density of $H$. akashiwo exceeded $10^{4}$ cells $\mathrm{ml}^{-1}$ 

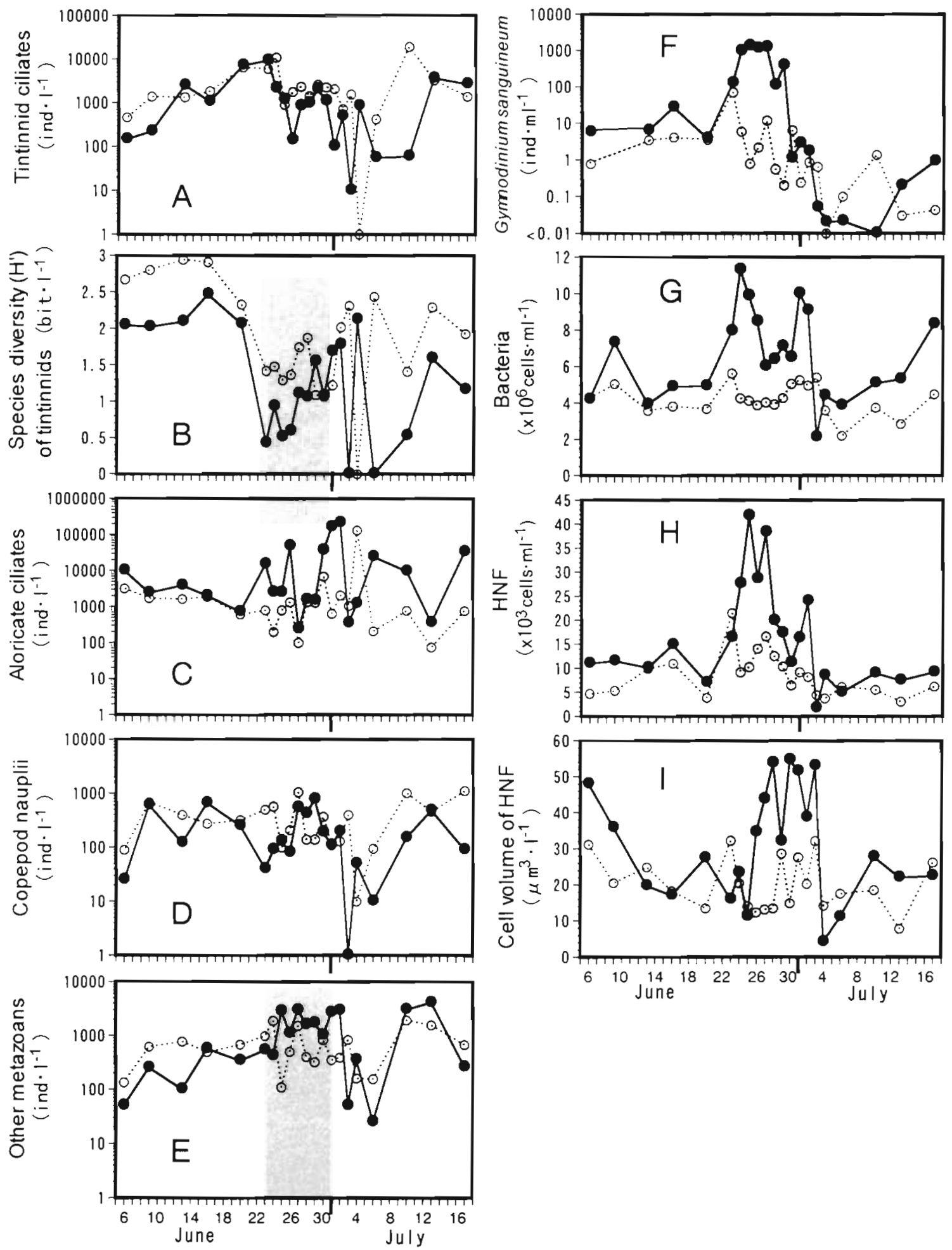

Fig. 2. Temporal changes in the abundance of microbial loop components (bacteria, heterotrophic nanoflagellates [HNF] and ciliates), species diversity of tintinnids, metazoan abundance and cell volume of HNF at the surface ( $)$ and $1 \mathrm{~m}$ above the bottom (O) during the course of a Heterosigma akashiwo bloom. Shaded areas indicate the bloom period (June 23 to July 1, 1995) when the density of $H$. akashiwo exceeded $10^{4}$ cells $\mathrm{ml}^{-1}$ 


\section{Bacteria and HNF}

Bacterial abundance ranged from 3.5 to $7.3 \times 10^{6}$ cells $\mathrm{ml}^{-1}$ in both layers before the bloom. In the surface layer, the bacterial population increased during the course of the bloom (Fig. 2G). Two abundance peaks were recorded just after the beginning and just after the end of the bloom. A maximum abundance of $11.3 \times 10^{6}$ cells $\mathrm{ml}^{-1}$ was detected in the surface layer on June 24 .

$\mathrm{HNF}$ abundance ranged from 3.9 to $14.9 \times 10^{3}$ cells ml $^{-1}$ in both layers before the bloom (Fig. $2 \mathrm{H}$ ). The bloom formation led to an increase of HNF abundance in a similar pattern as for bacteria. Fluctuations in HNF abundance were found to be tightly coupled with those of bacterial abundance; there were 2 abundance peaks detected after 1 to $3 \mathrm{~d}$ of the bacterial abundance peaks. During the bloom, the maximum abundance in the surface layer exceeded $41.7 \times 10^{3}$ cells $\mathrm{ml}^{-1}$ on June 25 . The cell volume of HNF during the later stage and at the end of the bloom increased to a level 2 or 3 times higher than that in the early stage of the bloom (Fig. 2I).

\section{Changes in the biomass of microbial loop components}

The biomass of bacteria and HNF in both layers ranged from 29 to $149 \mu \mathrm{g} \mathrm{C} \mathrm{l}^{-1}$ (mean value in both layers: 40 to $103 \mu \mathrm{g} \mathrm{Cl}^{-1}$ ) and from 3 to $117 \mu \mathrm{g} \mathrm{Cl}^{-1}$ (mean value in both layers: 40 to $66 \mu \mathrm{g} \mathrm{C} \mathrm{l}^{-1}$ ), respectively (Fig. 3). Although the mean biomass ratio of HNF to

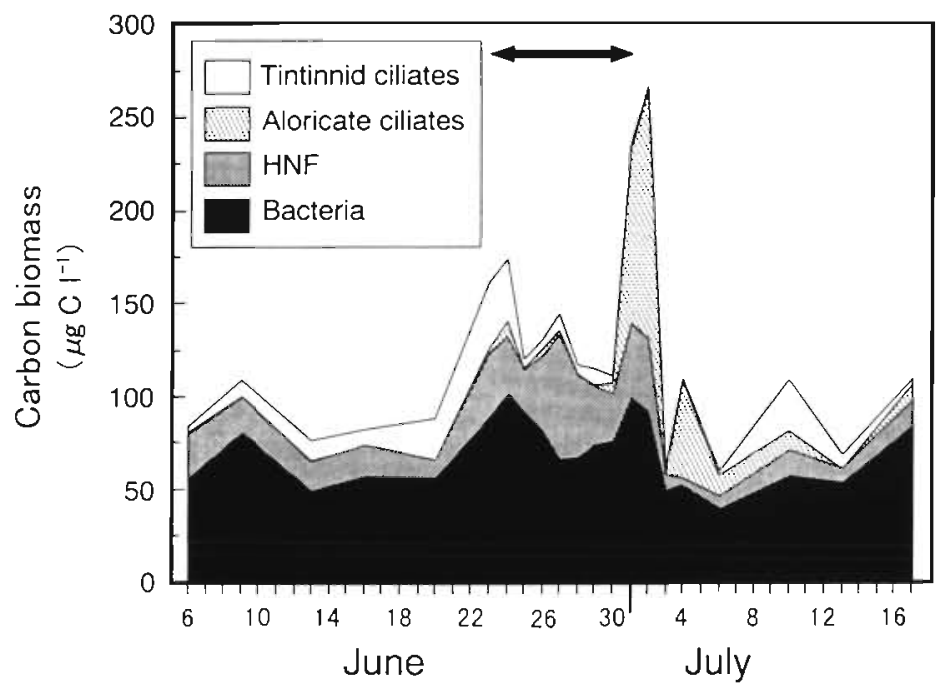

Fig. 3. Temporal changes in the carbon biomass of bacteria, HNF and ciliates during the course of a Heterosigma akashiwo bloom. The arrow indicates the bloom period (June 23 to July 1, 1995) when the density of $H$. akashiwo exceeded $10^{4}$ cells $\mathrm{ml}^{-1}$ bacteria in both layers ranged from 6 to $42 \%$ during the periods before and after the bloom, the ratio increased during the bloom and reached $100 \%$ on June 27 .

The biomass of the ciliate community was dominated by tintinnids before the bloom. At the early stage of the bloom, the maximum tintinnid biomass was recorded at $35 \mu \mathrm{g} \mathrm{Cl}^{-1}$ - this was 10 times as large as the biomass of aloricate ciliates. However, the dominance of ciliated protozoans shifted from tintinnids to aloricate ciliates when the bloom decayed. The biomass of aloricate ciliates increased substantially on July 1 to exceed the bacterial biomass $\left(134 \mu \mathrm{g} \mathrm{Cl}^{-1}\right)$.

\section{DISCUSSION}

The bloom of Heterosigma akashiwo occurred at surface temperatures between 21.6 and $23.2^{\circ} \mathrm{C}$. During a different time period (May 30 to June 4) in 1994, we also observed the formation of a $H$. akashiwo bloom in the same area when surface temperatures ranged from 19 to $21^{\circ} \mathrm{C}$ (Kamiyama et al. unpubl. data), suggesting that the outbreak of this bloom is associated with surface temperatures around $20^{\circ} \mathrm{C}$. Excystment of $H$. akashiwo occurs actively at around $20^{\circ} \mathrm{C}$ in marine sediments (Yamochi 1989), which might cause the appearance of vegetative cells in the water column and may be a trigger for the bloom. Before the bloom, large influxes of nutrients into the water column were not observed, indicating that nutrient conditions were not directly related to the formation of the blooms. In the present study, a large amount of rainfall could be one of the main causes of the disappearance of the H. akashiwo population. Before the sudden decrease of surface salinity, part of the $H$. akashiwo population moved from the surface layer to the near bottom layer on July 2, and then disappeared. This implies that there were other factors causing the collapse of the $H$. akashiwo bloom. Kim et al. (1998) demonstrated that $H$. akashiwo-killing bacteria contributed to the termination of this bloom at the same site as in this study.

The abundance of Gymnodinium sanguineum increased with increasing densities of Heterosigma akashiwo. This dinoflagellate is mixotrophic and can feed on ciliates and other phytoplankton (Bockstahler \& Coats 1993, Li et al. 1996). Hence, there is a possibility that development of the $G$. sanguineum population was due to active feeding on these organisms during the formation of the bloom.

In Hiroshima Bay, 2 studies have reported that the seasonal abundance levels of bacteria and HNF were 1 to $5 \times 10^{6}$ cells $\mathrm{ml}^{-1}$ and 1 to 
$10 \times 10^{3}$ cells $\mathrm{ml}^{-1}$, respectively (Iwamoto et al. 1994, Imai \& Yamaguchi 1996). Assuming the conversion factors of $0.14 \mathrm{pg} \mathrm{\mu m}^{-3}$ for bacteria (Nagata \& Watan-

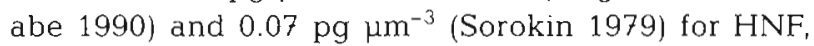
the biomass of these organisms were between 12 and $65 \mu \mathrm{g} \mathrm{C} \mathrm{l^{-1 }}$ and between 2 and $20 \mu \mathrm{g} \mathrm{C} \mathrm{l}^{-1}$, respectively. Imai \& Itoh (1984) showed that the maximum abundance and biomass of bacteria in Suo Nada, in the western part of the Seto Inland Sea, were $3.6 \times 10^{6}$ cells $\mathrm{ml}^{-1}$ and $30.8 \mu \mathrm{g} \mathrm{Cl}^{-1}$, respectively; those of $\mathrm{HNF}$ were $4.5 \times 10^{3}$ cells $\mathrm{ml}^{-1}$ and $9.0 \mu \mathrm{g} \mathrm{Cl}^{-1}$, respectively. The maximum values for bacteria (abundance: $11.3 \times$ $10^{6}$ cells $\mathrm{ml}^{-1}$, biomass: $149 \mu \mathrm{g} \mathrm{Cl}^{-1}$ ) and HNF (abundance: $41.7 \times 10^{3}$ cells $\mathrm{ml}^{-1}$, biomass: $117 \mu \mathrm{g} \mathrm{Cl}^{-1}$ ) in the present study exceeded those in adjacent marine areas. However, the maximum values in the present study are not excessively high when compared with the maximum abundance or biomass in Limfjorden, coastal Denmark (bacteria: $15.2 \times 10^{6}$ cells ml ${ }^{-1}$, HNF: $15.2 \times 10^{3}$ cells $\mathrm{ml}^{-1}$; Andersen \& Sørensen 1986) or those in the Marsdiep area of the North Sea (bacteria: ca $380 \mu \mathrm{g} \mathrm{C} \mathrm{l}^{-1}, \mathrm{HNF}$ : ca $270 \mu \mathrm{g} \mathrm{C} \mathrm{l}^{-1}$; van Boekel et al. 1992). Similarly, the maximum abundance and biomass levels of tintinnid and aloricate ciliates in this study $\left(2.15 \times 10^{5}\right.$ ind. $1^{-1}$ and $\left.268 \mu \mathrm{g} \mathrm{C}^{-1}\right)$ were higher than those in a eutrophic bay and in a variety of estu-

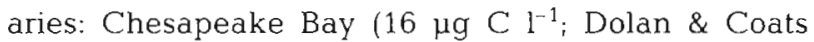
1990), Kiel Bight (56 $\mu \mathrm{g} \mathrm{C} \mathrm{I}^{-1}$; Smetacek 1981), Damariscotta estuary (33 $\mu \mathrm{g} \mathrm{C} \mathrm{^{-1 }}$; Revelante \& Gilmartin 1987), in Southampton water (141 $\mu \mathrm{g} \mathrm{C} \mathrm{I}^{-1}$; Leakey et al. 1992) and in the NW Mediterranean Sea $\left(2.60 \times 10^{4}\right.$ ind. $\mathrm{l}^{-1}$ and $96 \mu \mathrm{g} \mathrm{C} \mathrm{l}^{-1}$; Vaqué et al. 1997), and similar to data during a Phaeocystis bloom period in the Marsdiep area of the North Sea $\left(230 \mu \mathrm{g} \mathrm{C} \mathrm{I}^{-1}\right.$; van Boekel et al. 1992). The high abundance and biomass levels of bacteria, HNF and ciliates in this study indicate that the intense phytoplankton blooms increase to a large extent the flow of energy through the microbial loop.

The decrease of tintinnid ciliates detected during the bloom of Heterosigma akashiwo is a distinctive characteristic of the change in the microzooplankton community. Collapses of tintinnid ciliate populations by high densities of $H$. akashiwo have been reported in previous studies (Verity \& Stoecker 1982, Kamiyama 1995). The diversity of tintinnid species also decreased during the bloom, and this diversity was found to be inversely proportional to the density of $H$. akashiwo in this study (Fig. 4). A drastic decline of species diversity in the tintinnid community was also observed during a $H$. akashiwo bloom in Hiroshima Bay in 1994 (Kamiyama 1995). After the end of the bloom in this study, the abundance of tintinnids did not recover rapidly, because the extremely low salinity in the surface layer probably prevented tintinnids

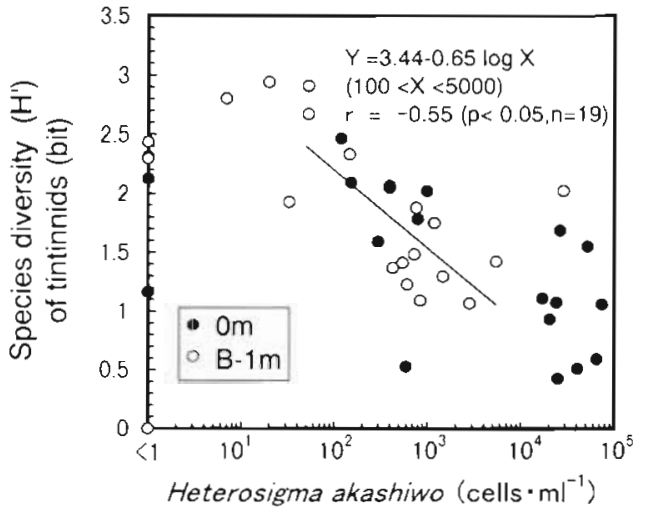

Fig. 4. Relationships between Heterosigma akashiwo abundance and the species diversity of tintinnid ciliates

from proliferating. Tintinnid population collapses are interpreted to be caused by the harmful effects of intracellular elements (Verity \& Stoecker 1982) or mucus (Egloff 1986) of $H$. akashiwo, which probably inhibit the consumption of $H$. akashiwo (Taniguchi \& Takeda 1988).

In general, an increase in bacteria coincides with an increase in chl a concentration indicating phytoplankton abundance (Bird \& Kalff 1984). In the present study, a positive correlation was observed between abundances of Heterosigma akashiwo and Prorocentrum spp. (more than 100 cells $\mathrm{ml}^{-1}$ ) and bacterial abundance (Fig. 5). Increases of bacterial abundance at the onset and at the end of the bloom were obvious, probably due to an increase in dissolved organic matter (DOM) produced by $H$, akashiwo and Prorocentrum spp. or by lysis of these algae. The increase of $\mathrm{PO}_{4}-\mathrm{P}$ concentration and the decrease of the Si:P ratio

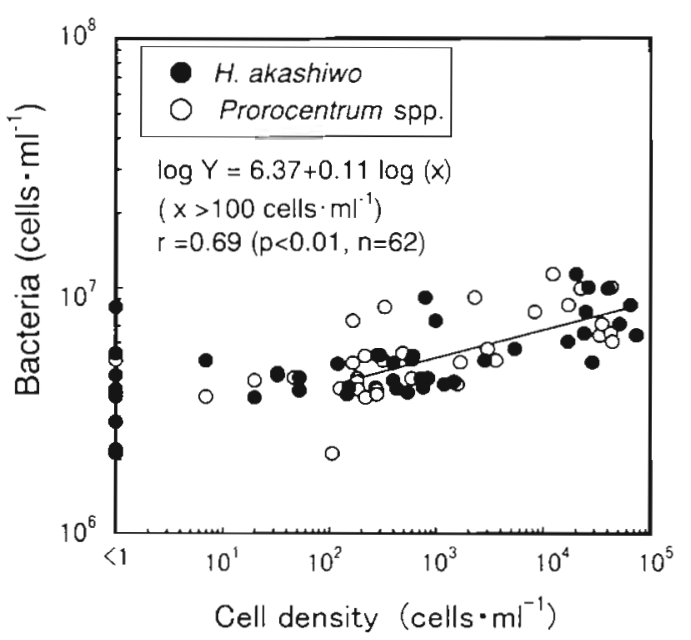

Fig. 5. Relationships between abundance of bacteria and Heterosigma akashiwo and Prorocentrum spp. 
in the B-1 $m$ layer around the end of the bloom (Fig. $1 \mathrm{G}, \mathrm{J}$ ) imply that bacteria actively produced $\mathrm{PO}_{4}-\mathrm{P}$ by mineralizing organic phosphorus originated from $H$. akashiwo and Prorocentrum spp. Cole (1982) reported that DOM, exuded by the abundant phytoplankton, promoted the development of a bacterial population. Van Boekel et al. (1992) reported that cell lysis after a Phaeocystis sp. bloom caused an increase in bacterial biomass. The temporary decrease of bacteria during the midterm of the bloom observed in the present study may be caused by the grazing control of HNF.

In short-interval investigations, peaks of bacterial abundance are usually followed by increases in HNF abundance with lag periods, which is the predatorprey oscillation. In the present study, 2 peaks of bacterial abundance observed just after the bloom formation and the collapse were followed by the peaks of HNF abundance with a 1 to $3 \mathrm{~d}$ lag period. This lag period is somewhat shorter than data ( 1 to $8 \mathrm{~d}$ ) in the other short-term investigations (Fenchel 1982, Andersen \& Sørensen 1986, Nakamura et al. 1994, Tanaka et al. 1997), implying that the increase of HNF rapidly responded to the increasing bacteria under conditions after the bloom formation and the decay. After July 2, the synchronization between bacteria and HNF abundance was observed. Tanaka \& Taniguchi (1999) demonstrated 6 factors that caused uncoupling and synchronization in the bacteria-HNF oscillation. Among them, physical disturbance due to much rainfall may strongly associate with the synchronization after June 2. Consequently, it is likely that short-lag and no-lag periods (synchronization) during and after the bloom caused significant correlation relationships between bacteria and HNF in the present study (Fig. 6).

An increase of aloricate ciliates at the end of the bloom is probably caused by the increases of bacteria

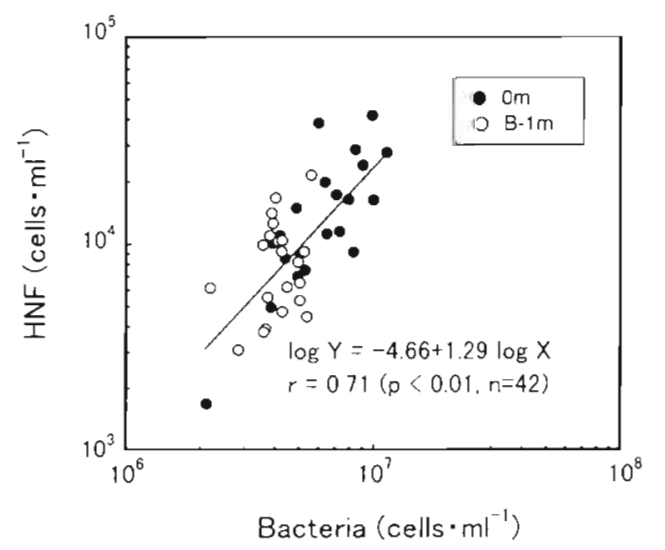

Fig. 6. Correlation between abundances of bacteria and HNF and HNF, indicating that the trophic energy in the microbial loop from DOM, bacteria and HNF was efficiently linked to aloricate ciliates at the end of the bloom. Such increase on the biomass basis between June 30 and July 1 was from 6 to $95 \mu \mathrm{g} \mathrm{Cl}^{-1}$. The potential specific growth rate during this period can be estimated to be $2.65 \mathrm{~d}^{-1}\left(=3.82\right.$ divisions $\left.\mathrm{d}^{-1}\right)$, based on the temperature $\left(23^{\circ} \mathrm{C}\right)$ and the mean cell volume of aloricate ciliates $\left(6100 \mu^{3}\right.$ ind..$\left.^{-1}\right)$ on July 1 , using the equation to estimate maximum growth rate of ciliates proposed by Müller \& Geller (1993). As a result, biomass of aloricate ciliates can potentially increase up to $87 \mu \mathrm{g} \mathrm{Cl}^{-1}$, which is similar to the actual biomass data

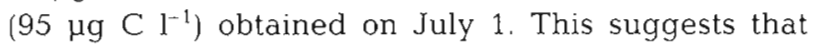
aloricate ciliates were reproducing at near-maximal rates with little loss to macrozooplankion predation. Kamiyama (1995) also observed temporal increases in small aloricate ciliates at the end of a $\mathrm{H}$. akashiwo bloom. Furthermore, Nielsen et al. (1990) reported that after the end of a harmful algal bloom of Chrysochromulina polylepis, microzooplankton accumulated at a specific layer where the alga had become concentrated.

In conclusion, a detailed investigation of microbial loop components revealed a drastic change in the food web systems during the course of the Heterosigma akashiwo bloom. In particular, it is clear that the bloom formation and decay enhanced the flow of energy within the microbial loop from the bacteria through the HNF to the aloricate ciliates. In spite of this, the energy flow to the tintinnids may be larger than that to the aloricate ciliates, except the bloom periods. We cannot specify the carbon budget between these organisms, since all the food sources of ciliates, such as picoplankton and autotrophic nanoflagellates, were not examined and information on heterotrophic and mixotrophic dinoflagellates except Gymnodinium sanguineum was lacking in the present research. Picoplankton are an important prey for HNF (Caron et al. 1991, Kuosa 1991) and ciliates (Bernard \& Rassoulzadegan 1990, 1993). Heterotrophic and mixotrophic dinoflagellates are also major consumers of nano- and microplankton (Lessard \& Swift 1985, Verity et al. 1993, Li et al. 1996). Further studies are needed to clarify the trophic interactions between these food web components in a highly productive marine environment where mechanisms within the food web system can be altered.

Acknowledgements. We thank Drs Y Morioka and T Uchida for their comments on the manuscript. Thanks are also extended to Mr M. Gotoh, the captain of RV 'Seto', for assistance with this research. This work was partly supported by a grant from the Fisheries Agency, Ministry of Agriculture, Forestry and Fisheries, Japan. 


\section{LITERATURE CITED}

Andersen P, Sørensen HM (1986) Population dynamics and trophic coupling in pelagic microorganisms in eutrophic coastal waters. Mar Ecol Prog Ser 33:99-109

Azam F, Fenchel T, Field JG, Gray JS, Meyer-Reil LA, Thingstad $F$ (1983) The ecological role of water-column microbes in the sea. Mar Ecol Prog Ser 10:257-263

Bernard C, Rassoulzadegan F (1990) Bacteria or microflagellates as a major food source for marine ciliates: possible implications for the microzooplankton. Mar Ecol Prog Ser $64: 147-155$

Bernard C, Rassoulzadegan F (1993) The role of picoplankton (cyanobacteria and plastidic picoflagellates) in the diet of tintinnids. J Plankton Res 15:361-373

Bird DF, Kalff J (1984) Empirical relationships between bacterial abundance and chlorophyll concentration in fresh and marine waters. Can J Fish Aquat Sci 41:1015-1023

Bockstahler KR, Coats DW (1993) Grazing of the mixotrophic dinoflagellate Gymnodinium sanguineum on ciliate populations of Chesapeake Bay. Mar Biol 116:477-487

Caron DA, Lim EL, Miceli G, Waterbury JB, Valois FW (1991) Grazing and utilization of chroococcoid cyanobacteria and heterotrophic bacteria by protozoa in laboratory cultures and a coastal plankton community. Mar Ecol Prog Ser 76: 205-217

Chang FH, Anderson C, Boustead NC (1990) First record of a Heterosigma (Raphidophyceae) bloom with associated mortality of cage-reared salmon in Big Glory Bay, New Zealand. NZ J Mar Freshw Res 24:461-469

Cole JJ (1982) Interactions between bacteria and algae in aquatic ecosystems. Ann Rev Ecol Syst 13:291-314

Cole JJ, Findlay S, Pace ML (1988) Bacterial production in fresh and saltwater ecosystems: a cross-system overview. Mar Ecol Prog Ser 43:1-10

Dolan JR, Coats DW (1990) Seasonal abundances of planktonic ciliates and microflagellates in mesohaline Chesapeake Bay waters. Estuar Coast Shelf Sci 31:157-175

Ducklow HW, Purdie DA, Williams PJ, Davies LeB (1986) Bacterioplankton: a sink for carbon in a coastal marine plankton community. Science 232:865-867

Egloff DA (1986) Effects of Olisthodiscus luteus on the feeding and reproduction of the marine rotifer Synchaeta cecilia. J Plankton Res 8:263-274

Fenchel T (1982) Ecology of heterotrophic microflagellates IV. Quantitative occurrence and importance as bacterial consumers. Mar Ecol Prog Ser 9:35-42

Hashimoto $\mathrm{H}$, Hashimoto T, Matsuda O, Tada K, Tamai K, Uye S, Yamamoto T (1997) Biological productivity of lower trophic levels of the Seto Inland Sea. In: Okaichi T, Yangai $T$ (eds) Sustainable development in the Seto Inland Sea Japan-from the viewpoint of fisheries. Terra Sci Publ, Tokyo, p17-58

Honjo T (1993) Overview on bloom dynamics and physiological ecology of Heterosigma akashiwo. In: Smayda TJ, Shimizu Y (eds) Toxic phytoplankton blooms in the sea. Elsevier Sci Publ, New York, p 33-41

Imai I, Itoh K (1984) Distribution of heterotrophic microflagellates in Suo-Nada, western Seto Inland Sea, in May 1983. Bull Nansei Reg Fish Res Lab 17:219-233 (in Japanese with English abstract)

Imai I, Yamaguchi M (1996) Seasonal fluctuations in abundance and production of bacteria, and quantitative relation with heterotrophic microflagellates in northern Hiroshima Bay, Seto Inland Sea. Bull Nansei Natl Fish Res Inst 29:76-86 (in Japanese with English abstract)

Iwamoto N, Imai I, Uye S (1994) Seasonal fluctuation in abun- dance of bacteria, heterotrophic nanoflagellates, autotrophic nanoflagellates and nanodiatoms in Hiroshima Bay, the Inland Sea of Japan. Bull Plankton Soc Jpn 41: $31-42$

Kamiyama $\Upsilon$ (1995) Change in the microzooplankton community during decay of a Heterosigma akashiwo bloom. J Oceanogr 51:279-287

Kamiyama T, Tsujino M (1996) Seasonal variation in the species composition of tintinnid ciliates in Hiroshima Bay, the Seto Inland Sea of Japan. J Plankton Res 18:2313-2327

Kim MuC, Yoshinaga I, Imai I, Nagasaki K, Itakura S, Ishida Y (1998) A close relationship between algicidal bacteria and termination of Heterosigma akáshiwo (Raphidophyceae) blooms in Hiroshima Bay, Japan. Mar Ecol Prog Ser 170: $25-32$

Kuosa H (1991) Picoplanktonic algae in the northern Baltic Sea: seasonal dynamics and flagellate grazing. Mar Ecol Prog Ser 73:269-276

Leakey RJG, Burkill PH, Sleigh MA (1992) Planktonic ciliates in Southampton water: abundance, biomass, production, and role in pelagic carbon flow. Mar Biol 114:67-83

Lessard EJ, Swift E (1985) Species-specific grazing rates of heterotrophic dinoflagellates in oceanic waters, measured with a dual-radioisotope technique. Mar Biol 87:289-296

Li A, Stoecker DK, Coats DW, Adam EJ (1996) Ingestion of fluorescently labeled and phycoerythrin-containing prey by mixotrophic dinoflagellates. Aquat Microb Ecol 10: $139-147$

Matsuyama Y, Kimura A, Fujii H, Takayama H, Uchida T (1997) Occurrence of a Heterocapsa circularisquama red tide and subsequent damages to shellfish in western Hiroshima Bay, Seto Inland Sea, Japan in 1995. Bull Natl Fish Res Inst 30:189-207 (in Japanese with English abstract)

Müller H, Geller W (1993) Maximum growth rate of aquatic ciliated protozoa: the dependence on body size and temperature reconsidered. Arch Hydrobiol 126:315-327

Nagasaki K, Ando M, Itakura S, Imai I, Ishida Y (1994) Viral mortality in the final stage of Heterosigma akashiwo (Raphidophyceae) red tide. J Plankton Res 16:1595-1599

Nagata T, Watanabe Y (1990) Carbon- and nitrogen-to-volume ratios of bacterioplankton grown under different nutritional conditions. Appl Environ Microbiol 56: 1303-1309

Nakamura Y, Fukami K, Sasaki S, Hiromi J (1994) Population dynamics of bacteria and heterotrophic nanoflagellates following the summer diatom bloom in the Seto Inland Sea. Bull Plankton Soc Jpn 41:1-8

Nielsen TG, Kiørboe T, Bjornsen PK (1990) Effects of a Chrysochromulina polylepis subsurface bloom on the planktonic community. Mar Ecol Prog Ser 62:21-35

Pierce RW, Turner JT (1992) Ecology of planktonic ciliates in marine food webs. Rev Aquat Sci 6:139-181

Porter KG, Feig YS (1980) The use of DAPI for identifying and counting aquatic microflora. Limnol Oceanogr 25:943-948

Putt M, Stoecker DK (1989) An experimentally determined carbon:volume ratio for marine 'oligotrichous' ciliates from estuarine and coastal waters. Limnol Oceanogr 34: $1097-1103$

Revelante N, Gilmartin M (1987) Seasonal cycle of the ciliated protozoan and micrometazoan biomass in a Gulf of Maine Estuary. Estuar Coast Shelf Sci 25:581-598

Shannon CE, Weaver W (1963) The mathematical theory of communication. Univ Illinois Press, Urbana

Sherr B, Sherr E (1983a) Enumeration of heterotrophic microprotozoa by epifluorescence microscopy. Estuar Coast Shelf Sci 16:1-7

Sherr EB, Sherr BF (1983b) Double-staining epifluorescence 
technique to assess frequency of dividing cells and bacterivory in natural populations of heterotrophic microprotozoa. Appl Environ Microbiol 46:1388-1393

Sherr BF, Sherr EB (1987) High rates of consumption of bacteria by pelagic ciliates. Nature 325:710-711

Sherr BF, Sherr EB (1988) Role of microbes in pelagic food webs: a revised concept. Limnol Oceanogr 33:1225-1227

Sherr EB, Sherr BF, Paffenhöfer GA (1986) Phagotrophic protozoa as food for metazoans: a 'missing' trophic link in marine pelagic food webs? Mar Microb Food Webs 1. $61-80$

Sieburth JMcN (1984) Protozoan bacterivory in pelagic marine waters. In: Hobbie JE, Williams PJLeB (eds) Heterotrophic activity in the sea. Plenum Press, New York, p 405-444

Simon M, Cho BC, Azam F (1992) Significance of bacterial biomass in lakes and the ocean: comparison to phytoplankton biomass and biogeochemical implications. Mar Ecoil Prog Ser 86:103-110

Smetacek V (1981) The annual cycle of protozooplankton in the Kiel Bight. Mar Biol 63:1-11

Sorokin Yu I (1979) Zooflagellates as a component of the community of eutrophic and oligotrophic waters in the Pacific Ocean. Oceanology 19:316-319

Stoecker DK, Capuzzo JMcD (1990) Predation on protozoa: its importance to zooplankton. J Plankton Res 12:891-908

Strickland JDH, Parsons TR (1968) A practical handbook of seawater analysis. Bull Fish Res Board Can 167

Suzuki R, Ishimaru T (1990) An improved method for the determination of phytoplankton chlorophyll using $\mathrm{N}, \mathrm{N}$ dimethylformamide. J Oceanogr Soc Jpn 46:190-194

Tanaka T, Taniguchi A (1999) Predator-prey eddy in heterotrophic nanoflagellate-bacteria relationships in a bay

Editorial responsibility: William $L i$,

Dartmouth, Nova Scotia, Canada on the northeastern Pacific coast of Japan. Mar Ecol Prog Ser 179:123-134

Tanaka T, Fujita N, Taniguchi A (1997) Predator-prey eddy in heterotrophic nanoflagellate-bacteria relationships in a coastal marine environment: a new scheme for predatorprey associations. Aquat Microb Ecol 13:249-256

Taniguchi A, Takeda Y (1988) Feeding rate and behavior of the tintinnid ciliate Favella taraikaensis observed with a high speed VTR system. Mar Microb Food Webs 3:21-34

Uye S, Takamatsu K (1990) Feeding interactions between planktonic copepods and red-tide flagellates from Japanese coastal waters. Mar Ecol Prog Ser 59:97-107

van Boekel WHM, Hansen FC, Riegman R, Bak RPM (1992) Lysis-induced decline of a Phaeocystis spring bloom and coupling with the microbial foodweb. Mar Ecol Prog Ser $81: 269-276$

Vaquẻ D, Blough HA, Duarte CM (1997) Dynamics of ciliate abundance, biomass and community composition in an oligotrophic coastal environment (NW Mediterranean). Aquat Microb Ecol 12:71-83

Verity PG, Langdon C (1984) Relationships between lorica volume, carbon, nitrogen, and ATP content of tintinnids in Narragansett Bay. J Plankton Res 6:859-868

Verity PG, Stoecker D (1982) Effects of Olisthodiscus luteus on the growth and abundance of tintinnids. Mar Biol 72: $79-87$

Verity PG, Stoecker DK, Sieracki ME, Burkill PH, Edwards ES, Tronzo CR (1993) Abundance, biomass, and distribution of heterotrophic dinoflagellates during the North Atlantic spring bloom. Deep-Sea Res 40:227-244

Yamochi S (1989) Mechanisms for outbreak of Heterosigma akashiwo red tide in Osaka Bay, Japan. Bull Osaka Pref Fish Exp Stn 8:1-110 (in Japanese with English abstract)

Submitted: May 26, 1999; Accepted: November 1, 1999

Proofs received from author(s): December 27, 1999 